
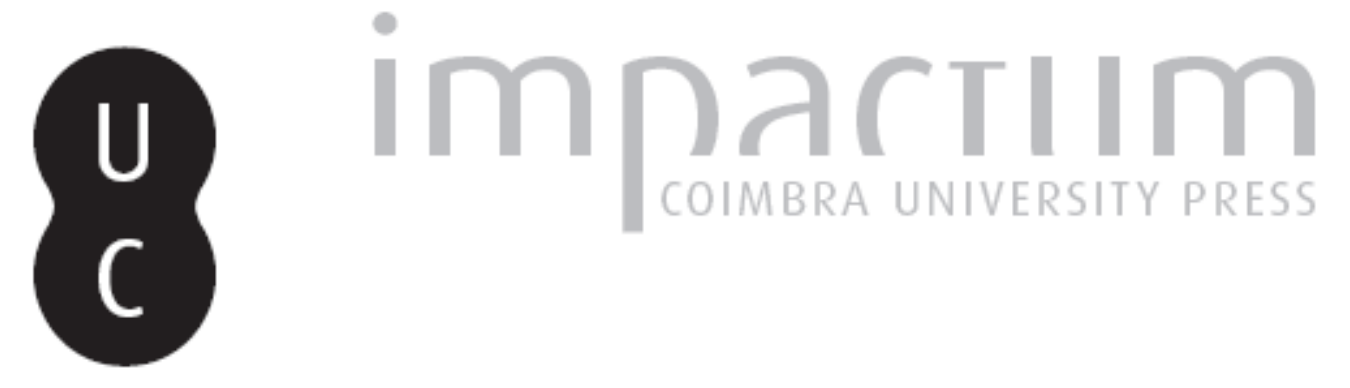

\title{
[Recensão a] As misérias do processo penal (Francesco Carnelutti, trad. Ricardo Rodrigues Gama, 2009)
}

\author{
Autor(es): $\quad$ Maduro, Flávio Mirza \\ Publicado por: Universidade Católica de Petrópolis \\ URL \\ persistente: \\ URI:http://hdl.handle.net/10316.2/33715 \\ DOI: \\ DOl:http://dx.doi.org/10.14195/2175-0947_5-1_10
}

Accessed : $\quad$ 26-Apr-2023 14:03:29

A navegação consulta e descarregamento dos títulos inseridos nas Bibliotecas Digitais UC Digitalis, UC Pombalina e UC Impactum, pressupõem a aceitação plena e sem reservas dos Termos e Condições de Uso destas Bibliotecas Digitais, disponíveis em https://digitalis.uc.pt/pt-pt/termos.

Conforme exposto nos referidos Termos e Condições de Uso, o descarregamento de títulos de acesso restrito requer uma licença válida de autorização devendo o utilizador aceder ao(s) documento(s) a partir de um endereço de IP da instituição detentora da supramencionada licença.

Ao utilizador é apenas permitido o descarregamento para uso pessoal, pelo que o emprego do(s) título(s) descarregado(s) para outro fim, designadamente comercial, carece de autorização do respetivo autor ou editor da obra.

Na medida em que todas as obras da UC Digitalis se encontram protegidas pelo Código do Direito de Autor e Direitos Conexos e demais legislação aplicável, toda a cópia, parcial ou total, deste documento, nos casos em que é legalmente admitida, deverá conter ou fazer-se acompanhar por este aviso.

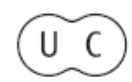



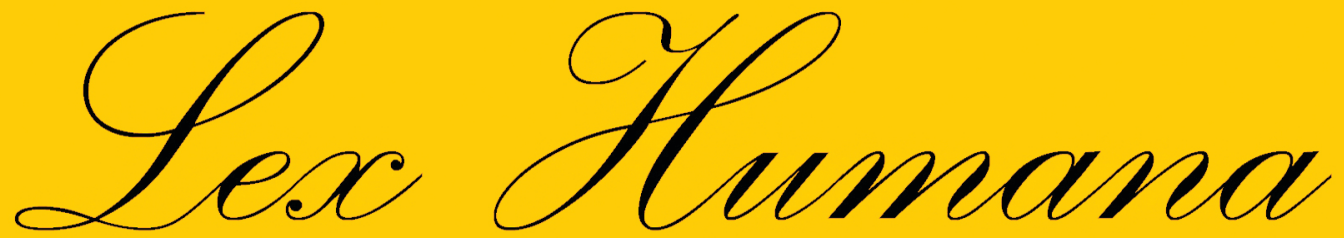

Revista do Programa de Pós-Graduação em Direito da UCP

ISSN(e) 2175-0947

Universidade Católica de Petrópolis Rua Benjamin Constant, 213 - Petrópolis - Centro CEP 25610-130

Tel: (24) 2244-4000 E-mail: lexhumana@ucp.br 


\section{As Misérias do Processo Penal \\ (Francesco Carnelutti, trad. Ricardo Rodrigues Gama, 2009)}

FLÁVIO MirZa MADURO*

UNIVERSIDAde CATÓlica DE PETRÓPOLIS, BRASIL

Francesco Carnelutti é, junto com Giuseppe Chiovenda, considerado um dos maiores processualistas italianos.

No início da carreira docente, lecionava disciplinas ligadas à área cível. Migrou para a seara criminal e, no final de sua carreira, lecionava Direito Processual Penal em Roma.

Era um liberal e um católico fervoroso. Tal religiosidade influenciava suas ideias e sua obra que, no início, era, eminentemente, jurídica e, no final de sua vida, possuía caráter filosófico.

Morreu em 1965, contando 86 (oitenta e seis) anos de idade.

Sua contribuição para a Ciência Processual é inestimável.

Em linhas gerais, a obra, As Misérias do Processo Penal, que continua atual, posto que escrita no século passado, desnuda as agruras do processo penal. O imenso sofrimento do réu, o papel dos atores processuais e toda carga que envolve a persecução penal e suas consequências para o status dignitatis do acusado.

Como dizia Carnelutti, o réu é coisa sagrada.

No primeiro capítulo, denominado A Toga, inicia chamando a atenção para um aspecto cênico dos julgamentos, qual seja: a toga. Observa o autor que em alguns países ela não é usada, enquanto em outros, de maior solenidade, como o Reino Unido, p. ex., o advogado deve portála a todo tempo. Comenta que a toga convida ao isolamento e que a função judiciária está ameaçada pelos perigos da indiferença e/ou do clamor popular.

Demonstra como a publicidade opressiva da imprensa desvirtua o caráter de publicidade, pois o que se busca finda por ser o achincalhamento do acusado.

No capítulo II, trata da figura do preso que se contrapõe à figura dos homens de toga.

\footnotetext{
* Doutor em Direito pela Universidade Gama Filho, Brasil. Professor do Mestrado em Direito da Universidade Católica de Petrópolis, Brasil. Currículo lattes: http://lattes.cnpq.br/4526253051246397. E-mail: fmirza@,connection.com.br.
} 
Sustenta que o mais pobre dos pobres é o encarcerado. Não o faminto ou o vagabundo, mas o preso.

Nessa toada, traz à baila as algemas, afirmando serem um símbolo do Direito.

Faz críticas ao encarceramento e à pena, aludindo aos ensinamentos de Cristo e São Francisco de Assis. Segundo o autor, os sábios continuam a imaginar que a pena é um mal que sofre o delinquente pelo mal que causou. E, finaliza, pautado em Jesus Cristo que “(...) não é com o mal que se pode vencer o mal.”

Após experiência de trabalho com um homicida, aduz que o germe do bem, em qualquer pessoa, está sempre aprisionado. E mais, que estamos todos, em maior ou menor grau, numa prisão, pois ficamos fechados em nós mesmos, em atitude egoísta. Segundo Carnelutti, o delito é a "explosão do egoísmo".

No terceiro capítulo, trata da figura do advogado que não faz só um trabalho técnico, como o médico ou o engenheiro.

Em verdade, o advogado oferece proteção, é o patrono. Segundo o autor italiano, a essência e a nobreza da advocacia estão no fato de que o advogado deve permanecer ao lado do acusado, mesmo no último degrau, ou seja, no momento mais difícil. Adverte que as pessoas em geral, e até os juristas, não entendem e nutrem certa antipatia pelo advogado. Mas, o advogado deve pedir, suplicar, e isso seria um exercício espiritual saudável.

No capítulo IV, entram em cena o juiz e as partes.

O juiz, como já afirmado em prestigiosa sede doutrinária, é o mocinho do filme, ou, como diz Carnelutti, é aquele que está "no ponto mais alto da escala".

As partes são os sujeitos que possuem interesses opostos e que serão julgados pelo juiz. Mesmo estando acima das partes, o juiz é um homem (e, portanto, parte de algo, daí seu drama). Interessante notar que Carneluttti já antevia discussão que se tornou mais acalorada no início do século XXI, qual seja: o equívoco que representa a posição na sala de audiência, com a defesa sentada em plano inferior ao do juiz e o Ministério Público sentado ao lado do mesmo. Dizia ele que isso haveria de ser corrigido com o tempo. Lamentavelmente, em terrae brasilis, não o foi.

Julgar o outro é extremamente difícil, daí dizer-se que julgar é uma função que o homem usurpou de Deus. Carnelutti fala num verdadeiro drama, pois qualquer um que refletisse um pouco veria a dificuldade em ser juiz, mas o Direito precisa deles. Aduz que o colegiado (órgão composto de vários julgadores) seria um modo de minorar danos e assegurar a dignidade do julgador. Ou seja, o colegiado seria “(...) um remédio contra a insuficiência do juiz, (...)”. Finda por vaticinar que a justiça humana é uma justiça parcial e será pior (e mais parcial) caso não haja amor pelo próximo (pela figura humana). 
No capítulo V, Carnelutti fala da parcialidade do defensor (e do acusador) que é um "raciocinador". Trata-se de alguém que ajuda o juiz a raciocinar, trazendo suas razões (claro que de modo parcial) que não podem ser ignoradas.

Entra em cena o contraditório!

Carnelutti aduz que embora possa parecer absurdo que haja duas verdades, a da defesa e a da acusação, isso é salutar para que o Juízo do magistrado não seja um escândalo. Reafirma que a figura do advogado é uma das mais discutidas na sociedade, mas que sua parcialidade é salutar para a formação do convencimento do magistrado.

Quando vai discorrer sobre as provas, no capítulo VI, inicia dizendo que a “(...) missão do processo penal está no saber se o acusado é inocente ou culpado".

Para se falar em culpa ou inocência, é preciso fazer história, ou seja, é preciso reconstruir um fato (um momento) histórico e as provas servem para isso. Alerta que, não raro, nessa reconstrução são feitos juízos açodados, que massacram o indivíduo, que nem sequer foi condenado e já é considerado culpado. Faz-se, pois, tábula rasa das garantias insculpidas na Constituição Italiana de preservação da dignidade do investigado.

No capítulo VII, ao discorrer sobre o juiz e o acusado, volta a reafirmar o papel de historiador do primeiro. Mas, adverte que o papel de pesquisador (historiador) do juiz não se restringe à mera reconstrução fática dos aspectos externos. Deve ele investigar a alma (o espírito ou psique) do acusado. Isso, contudo, deve ser feito com cautela, pois o perigo é atribuir ao outro a nossa alma. Ou seja, julgar o outro de acordo com o que sentimos, pensamos, queremos.

Obviamente, o ato de julgar toma como partida a ação, mas não se esgota nela. Assim, o juiz deve ter paciência para apreender toda a história do acusado. Mas, o processo penal sempre será imperfeito, sem que isso o desacredite.

No capítulo VIII, Carnelutti adverte que o passado (ou seja, o que está feito) não pode ser desfeito e que o remédio, a solução, está no futuro. Sustenta que o desinteresse pelo futuro é uma das características da crise do processo penal.

Sustenta que não se pode ir contra a lei, mas que o juiz - jurista - às vezes se esquece do homem ao dar primazia aos tipos penais. Aduz que não se pode pensar num mundo abstrato ao invés de um concreto, pois transformaria os homens em fantoches.

Constata, outrossim, que o Direito e muito menos o processo podem fazer milagres.

No capítulo IX, chega-se à sentença, pois, reconstruído o fato histórico-criminoso e aplicada a lei, o acusado vai ser absolvido ou condenado. 
Em verdade, o processo não termina nunca, é uma pena eterna (quando o acusado é absolvido por falta de provas). A absolvição envolve o reconhecimento de um erro judiciário. E, a coisa julgada é, em última análise, uma substituição da verdade.

Havendo condenação, o processo não acaba totalmente, conforme inicia o capítulo X.

A pena tem a função de punir o culpado e servir para mostrar a todos que não devem delinquir. E, mesmo grave o castigo, a pena, não exclui o amor (lança mão de uma metáfora dizendo que o pai castiga o filho, que erra, porque o ama - assim também a sociedade pune o condenado).

No capítulo XI, Carnelutti trata da libertação. Nesse momento, para o encarcerado, o processo penal termina.

Mas, o grande problema é o estigma. O preso já não se vê mais como tal, pois cumpriu sua pena, mas a sociedade ainda o encara como preso e discrimina. Como sustenta o autor, é um ato assaz cruel.

Finalmente, no capítulo XII, derradeiro, diz que talvez seja possível compreender como o caso penal afeta a sociedade.

O Direito deve (ou deveria) fazer com que os homens se respeitem. É preciso que haja civilidade e compaixão. Entretanto, vaticina que os homens preferem julgar a amar.

Enfim, a obra demonstra como o processo penal é imperfeito, notadamente por ser feito por homens. E, que o acusado dever ser respeitado e tratado com dignidade, como princípio de civilidade. A dignidade humana é um valor em si, é intrínseco ao ser humano e não uma qualidade que se tem ou não dependendo de sua posição.

\section{Referência bibliográfica}

CARNELUTTT, Francesco. As Misérias do Processo Penal, trad. Ricardo Rodrigues Gama, $2^{\mathrm{a}}$ ed., Campinas: Russell Editores, 2009. p. 94. ISBN: 978-85-89251-98-3. 